\title{
Article
}

\section{Employing dwelling to re-consider individual and collaborative relationships to pedagogical practice}

Giddens, Sara, Long, Elizabeth and Spencer, Ruth Margaret

Available at http://clok.uclan.ac.uk/22686/

Giddens, Sara ORCID: 0000-0003-0680-2189, Long, Elizabeth and Spencer, Ruth Margaret (2018) Employing dwelling to re-consider individual and collaborative relationships to pedagogical practice. Journal of Dance \& Somatic Practices, 10 (1). pp. 52-64. ISSN 1757-1871

It is advisable to refer to the publisher's version if you intend to cite from the work. https://doi.org/10.1386/jdsp.10.1.52_1

For more information about UCLan's research in this area go to http://www.uclan.ac.uk/researchgroups/ and search for <name of research Group>.

For information about Research generally at UCLan please go to http://www.uclan.ac.uk/research/

All outputs in CLoK are protected by Intellectual Property Rights law, including Copyright law. Copyright, IPR and Moral Rights for the works on this site are retained by the individual authors and/or other copyright owners. Terms and conditions for use of this material are defined in the policies page.

\section{CLoK}

Central Lancashire online Knowledge www.clok.uclan.ac.uk

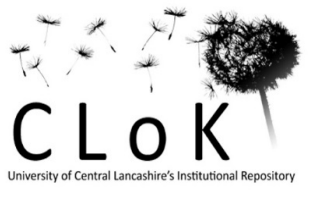


PAUSE [...]

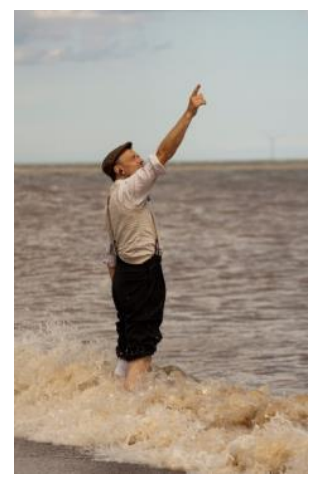

Figure 1

BREATHE [...]

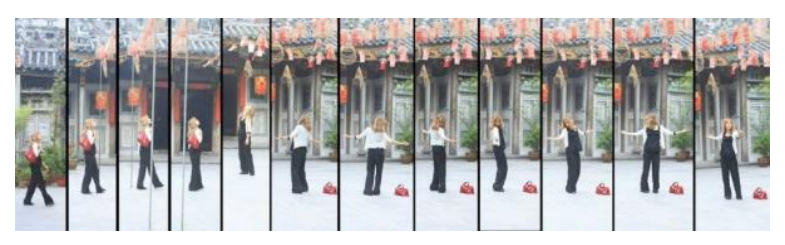

Figure 2

BECOME AWARE [...] 


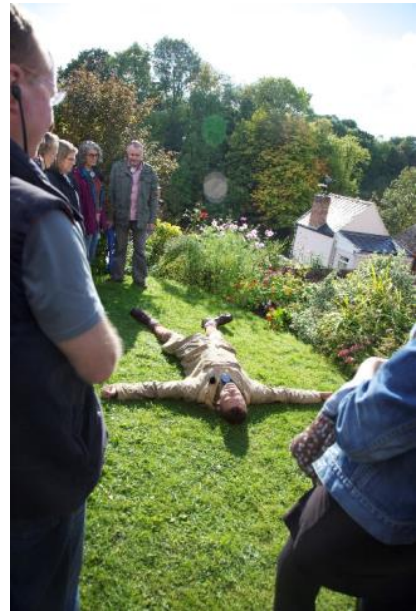

Figure 3.

How have we arrived here in this moment? Through movement? Making the stopping and still-ing more profound in its difference. Doing stillness by way of movement, but just as readily finding movement through stillness. Arriving at this dwelling point, here and now. Still alone together. And in this somehow shared space-time, clearing a space so it can be filled again by you and your own theres and thens.

\section{Journal Notes made during making and} reflection of The Dream-Walks. 


\title{
Employing dwelling to re-consider individual and collaborative relationships to
} pedagogical practice

Sara Giddens, Liz Long and Ruth Spencer, University of Central Lancashire

\begin{abstract}
Three practitioner-researchers from the University of Central Lancashire begin to wrestle with how they might employ dwelling within their pedagogy. Weaving together images and texts from a diverse range of sources, they invite readers to consider how dwelling, as a practice, has become, foregrounded in, and through their research and professional practice, and how it might support and challenge teaching and learning within a higher education context. How it might inform and empower new ways of working collaboratively and help us to enable and engage in a more useful and meaningful dialoguing process.
\end{abstract}

\section{Keywords}

dwelling

somatic practice

choreography

pedagogy

Bodies in Flight

Heidegger

Claxton 
higher education

\section{Introduction}

Perhaps it is useful to outline a little why we find ourselves considering how we might employ dwelling as a pedagogical practice. Having worked together as teaching colleagues over the last three years, we have become increasingly concerned with the crossover points between our diverse and complimentary practices, namely choreography, somatics and teaching, for us as pedagogues and for our students. Moreover, lately we feel a little emboldened by the possibilities that we might construct as part of a very newly formed research collective.

In different ways, we have made a commitment to employing dwelling as a process to frame and support this. We are curious as to how we might dwell together, how we might imagine and re-imagine ways of being together through our complimentary practices, and how this might impact upon our teaching and learning, and fundamentally upon the experience for and of our students.

We are experienced practitioners. We know that each new collaboration, each new encounter of practices and philosophies, demands a giving of ourselves as individuals. We are interested in how finding space-times to dwell with each other, might support us all to listen more completely, in our very many ways to each other and to our students.

\section{Doing things differently [...]}

By the time students join our course they have been part of the 'beast' that is our education system for the best part of thirteen years; thirteen years of being within a system that gives 
credence to what author and emeritus professor of learning sciences at the University of Winchester, Guy Claxton (1997: 7-9), sees as 'conscious, deliberate and purposeful thinking'. An education system that has trained our young people to be interested and adept in 'finding answers and solutions rather than in examining questions'. An education system that allows our young people to treat 'perception as unproblematic', to see thought as 'the essential problem solving tool' and asks that they are 'always [be] able to justify plans, to seek clarity and eradicate confusion', a system that encourages young people to work with a 'sense of urgency'.

When we offer these young dance artists time and space to dwell in not knowing they often display discomfort and resistance. Responses range from anger and denial to blind panic; students stick their heads in the sand or hang on relentlessly to what they already know.

Thinking processes often appear fixed and in grained, any display of not knowing the answer seen as a sign of weakness.

\section{Breathe $[\ldots]$}

\section{Where is the space?}

Find stillness $[\ldots]$ silence.

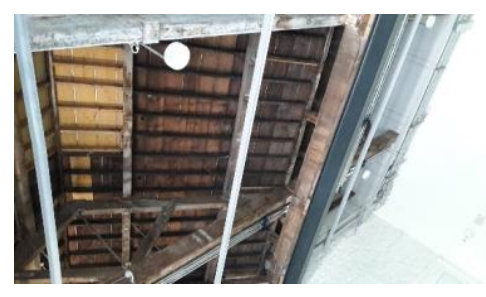

Figure 4. 
Sara writes $[\ldots]$

One possible history, of many, is that I came to dwelling - through my performance practice.

Over the last seven years, alongside my long-term collaborator Simon Jones (professor of performance at Bristol University) we, as Bodies in Flight, have been making a series of ambulant performance works, The Dream-walk.

Beginning in 2009 and originally conceived to take place in the early morning commute in Singapore and Nottingham, The Dream-walk asked audiences to follow the performers through the city streets, occasionally stepping aside and resting in places in-between the flow of the everyday commute.

Initial research in Bristol and Derbyshire enabled us to find a rhythm for the walks - the technology (a transmitter and receiver) demanded that the performers (who were mic'd) had to keep within a particular range, both of each other and their audiences. These audiences, these auditor-walkers, listened, through earphones, to a pre-recorded and live soundtrack operated by the musician, and made up of text, original composed music and ambient sounds taken from the surrounding environments. This technical demand became a guiding principle for the structuring of the walks.

I might articulate this now as a place between immediating (passing by the here and now) and dwelling. A movement from the immediate to staying put in one place for a while, perhaps beyond this here and now, a still-ing, that allowed a particular (though not of course unique) space-time for the opening up of memories and possibilities.

This distinction between the onward travelling motion, passing by the here and now to the just there then, to still-ing together, apparently sharing one space and time, evoked different 
tones. This oscillation opened up two distinct ways of being with or in the work. As we pressed forwards, we just had time to note, sometimes audibly, or perhaps just begin to comment upon the immediate things around and about us. If and when we stopped, it was because the performer stopped, and there was time for us (as makers, then spectators) to look more carefully.

It was in these gaps in the walking, where and when spaces opened up for us to take more time $[\ldots]$

$[\ldots]$ to notice more,

[...] to see and listen with more care.

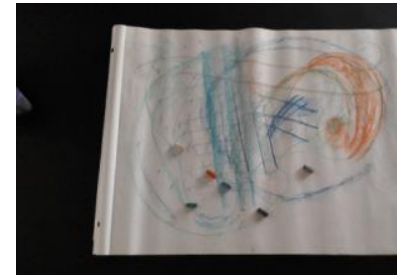

Figure 5 and 6.

Lizzie reflects $[\ldots]$.

My perception of the world around me and myself within it, my understanding, awareness and meaning arrive from my body and the senses. To fully understand myself within the world I need to take time to listen to my body, my own subjective experience of this moment. 


\section{What do I notice?}

To bring my awareness away from thoughts and words and into the body and the senses gives me a different, deeper understanding of myself, my experiences, what I noticed in the world around me, what impacts on me and my response to the world around me. It is from a place of dwelling that I can make a choice and have more agency in how I respond to the things that affect me.

From this place, I have more understanding of why I respond in a particular way. What brought me here to this place? What draws my attention? What meaning does this moment have for me? And why do I choose to respond in this way at this particular moment in time? I can only have this depth of questioning, awareness, and discovery, if I take time to listen to myself moment by moment.

As I breathe... what do I notice now? [...] And breathe [...] and what do I notice now? [...] as I write $[\ldots]$ I notice my heavy legs $[\ldots]$ heavy shoulders $[\ldots]$ the light on my eyes $[\ldots]$ tingling in my foot $[\ldots]$ as I imagine $[\ldots]$ and question $[\ldots]$ where is that in my body? [...] And breathe [...] My chest is tight [...] my teeth are clenched [...] there are a lot of thoughts in this moment $[\ldots]$ the space around me is dark [...] there is light on my page [...] I am focused on the writing $[\ldots]$ the words $[\ldots]$ And breathe $[\ldots]$ from my gut $[\ldots]$ the heart $[\ldots]$ the head $[\ldots]$ I am writing from these places in my body [...] And breathe.

It is the breathing, the pauses, that allows me to speak from the body and not the head. 
If my understanding of the world is in the body and the senses, then I want to allow myself to speak from this place.

In my day-to-day living thoughts can takeover. But the thoughts and thinking for me is the not knowing, the questioning, exploring, imagining. The body is the sensing, feeling, subjective experience, and a place where I know myself fully.

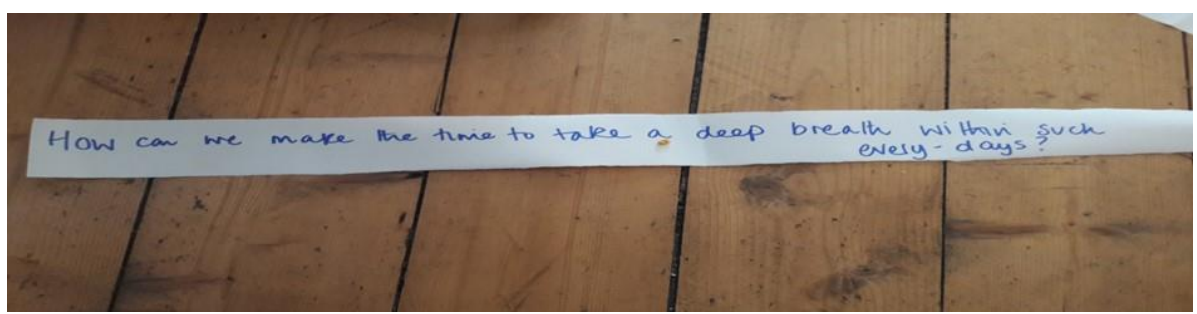

\section{Figure 7.}

The balance between the thinking and questioning, and the sensing and feeling allows me to make meaning of my experiences.

The breath, the spaces and the dwelling allows me to find balance, find more meaning and value of my existing, my being in this time and space.

Through dwelling, through still-ing, I have come to believe that we can re-approach dance and dancing from a space-time that is both more open and differently aware. I wonder how to 
create such an invitation to my students and their making processes? I wonder how useful they might find this, and I wonder how an inevitable slowing down might collude and collide with their experience so far of an education system that demands speed and knowledge, not still-ing and non-knowing. Through creating spaces to dwell in the Dream-walk, I have been practising (however unknowingly), 'attentive dwelling' (Heidegger [1956] 1978b: 150).

Through dwelling we were able to attend more closely to those things and places and people around and about us, and to ourselves. Through attentive listening we could hear more clearly, more completely more voices, with all the incompleteness that implies. Through dwelling, we became re-energised and re-acquainted with movement and the world and people around us.

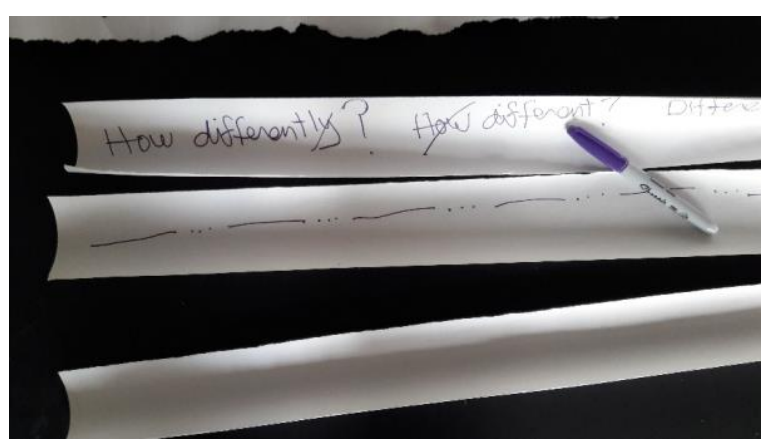

Figure 8.

Ruth considers how Claxton (1997: 6) reminds us that 'learning - the process of coming to know - emerges from uncertainty'. We want to support a way of working with our students within which 'not knowing', curiosity and inquiry are valued, where questions are answered with more questions. We want them to relish space to play, explore and discover, to respond intuitively and work from a balanced mind/body relationship. 
As we question and reflect upon the habits and practices of our students, we cannot help but reflect upon our practice as tutors.

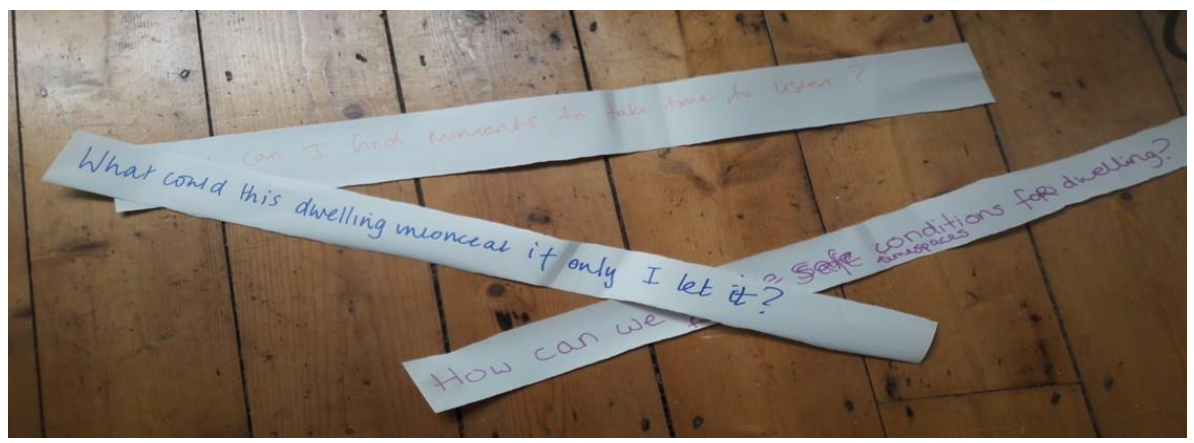

Figure 9.

\section{What are we modelling?}

The current environment of higher education in the United Kingdom is fast paced. Efficiency is key, with staff undertaking multi-faceted roles which often collide and compromise one another; researcher, educator, advisor, guide, administrator, marketer, outreach worker, etc. We are time strapped, deadline driven, dialogue poor, e-mail chasing, computer tied, committed educators.

How might dwelling play a role in supporting different ways of being?

We are starting to engage with the uncertainty of how to practice in light of these contexts.

The questions are arising $[\ldots]$

How is the culture of higher education influencing our practice as artists/ educators/researchers and, in turn, how is this culture affecting our students?

How might engagement with dwelling support deeper inquiry? 
How might still-ing allow space for movement towards other?

How do we move towards models of practice that supports time to ponder and time to rummage around ideas?

How might we do things differently?

Our dissemination began with the three of us leading a workshop at the practice-as-research NOW symposium at the National University of Ireland, Galway in May 2017, affording us the opportunity to 'bathe' ourselves in these concerns. Early reflections embolden us to, proactively, rethink our models of working.

Although we are only at the start of this process we recognise that engaging with dwelling-asa practice, has inevitably already led to a reflection upon our own rhythms, patterns, habits and a deeper analysis of the choices that we make in our every days, and more specifically within our teaching environs.

It seems to us, and again returning to Heidegger ([1951] 1978a: 347), that 'proper' dwelling carries with it a necessity to value and care for those beings and things within our 'domain'. Working from this premise, made us question to what extent our current systems and structures allowed us to do this. As we reflected upon our localised pedagogical domain, it became apparent that institutional patterns and procedures often stifled opportunities to dwell, short cutting dialogue, compartmentalising and over-emphasising product. In order to begin to combat this, we have made structural changes to timetables and modules; increasing and opening out inquiry spaces, creating opportunities for multiple voices, for difference, and situating studio-practice over longer, protected periods of time, calling into view our increasing embodied experience of practice as research. Such attention, has led to a foregrounding of practice, of guided reflection and critical dialogue as processes to prepare 
for and support 'attentive dwelling,' alongside the acknowledgement that somatic practices must be a part of, and not discrete from all modular delivery.

Journal Notes

Don’t rush,

we can dwell in the gaps,

we don't need to try and fill them.

I'm wondering how we dwell?

I'm wondering how we dwell together?

Being to being,

still together

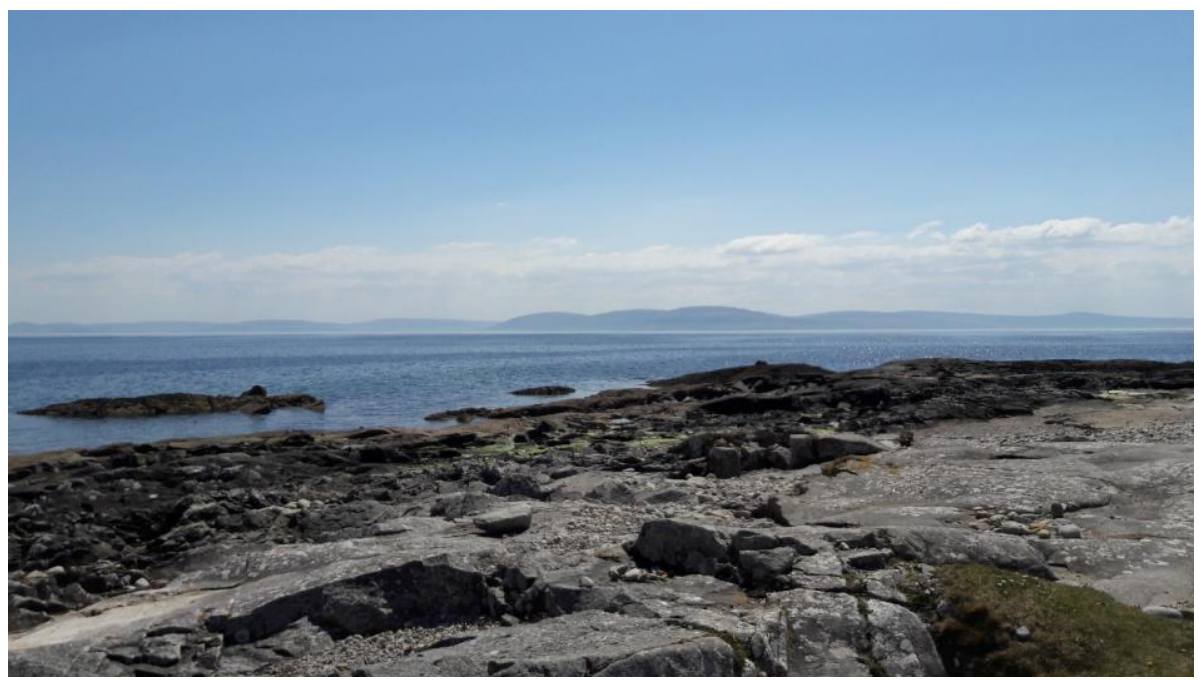

Figure 10. 


\section{References}

Bodies in Flight (2009), Dream-work, live performance, performed by Polly Frame and Sam Halmarack, Singapore, 24-29 June (Figure 2).

(2011), Dream-walk, live performance, performed by Neil Johnson and Graeme Rose,

Wirksworth, 18 September. (Figure 3).

(2012), Dream-walk, live performance, performed by Neil Johnson and Graeme Rose,

Skegness, 30 June-1 July. (Figure 1).

Bohm, D. (1998), On Creativity, London: Routledge.

Carter, R. E. (1995), Becoming Bamboo: Western and Eastern Explorations of the Meaning of Life, Quebec: McGill-Queens University Press.

(2001), 'The form of the formless: The healing journey from self to nothingness',

Journal of Inquiry and Research, 73, February, pp. 63-71.

Claxton, G. (1997), Hare Brain, Tortoise Mind, New York: Harper Collins.

Commented [S1]: Please provide issue number if available in this exact format, including connecting punctuation: Carter, R. E. (2001), 'The form of the formless: The healing journey from self to nothingness', Journal of Inquiry and Research, 73:x, February, pp. 63-71.

Commented [RMS2R1]: There is no issue number with this journal.

Eliot, T. S. ([1944] 1974), The Four Quartets, London: Faber. 
Heidegger, M. ([1951] 1978a), 'Building dwelling thinking', in D. Farrell Krell (ed.), Basic

Writings, London: Routledge, pp. 343-365.-

([1956] 1978b), 'The origin of the work of art', in D. Farrell Krell (ed.), Basic Writings,

London: Routledge, pp. 139-212.

(1966), Being and Time (trans. Joan Stambaugh), Albany: State University of New York

Press.

\section{Captions}

Figure 1: Dream-walk, Skegness, 2013. Photo: Tony Judge.

Figure 2: Dream-walk, Singapore, 2009. Photo: Yuen Chi Wai.

Figure 3: Dream-walk, Wirksworth, 2011. Photo: Tony Judge.

Figure 4: NUI Roof, Galway Conference, 2017. Photo: Ruth|Spencer.

Figure 5: Cuisle, Galway Conference, 2017. Photo: Ruth Spencer.

Figure 6: Breath drawing, Galway Conference, 2017. Photo: Ruth Spencer.

Figure 7: Breath within our everyday, Galway Conference, 2017. Photo: Ruth Spencer.

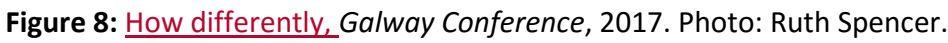

Figure 9: Unconceal, Galway Conference, 2017. Photo: Ruth Spencer.

Figure 10: Galway Bay, 2017. Photo: Ruth Spencer.

\section{Contributor details}


Dr. Sara Giddens is a choreographer and creative facilitator. She also teaches on the dance performance and teaching course at the University of Central Lancashire. Having worked on the 'Articulating Dance' project, as part of Choreographic Lab, Sara recently completed a practice-based Ph.D., co-hosted by Dance4 and Middlesex University. She continues to develop, make and tour performance-based work with Prof Simon Jones (Bristol University) through their company Bodies in Flight (1990).

Liz Long is passionate about developing creativity and the imagination through movement and somatic practices, enquiring into how developing self-awareness through reflective practice improves health and wellbeing. This viewpoint underscores her activities as an independent dance artist, somatic movement educator and a lecturer in higher education. She is interested in learning and development within education for children and working in community and health settings with adults.

Ruth Spencer makes, performs and facilitates dance. As a senior lecturer on the dance performance and teaching course at the University of Central Lancashire Ruth oversees the education- and community-based strands of practice. Ruth's own work as a performer and educator spans 30 years with a particular emphasis on nurturing creative autonomy through movement.

\section{Contact:}

University of Central Lancashire, Media Factory, Preston, PR1 2HE, UK.

E-mail: Sara Giddens: sgiddens@uclan.ac.uk

E-mail: Ruth Spencer: rmspencer2@uclan.ac.uk

E-mail: Liz Long: ELong1@uclan.ac.uk 
